GRUY FEDERAL, INC.

INVESTISATICN ARO EYALUATION C,F

GEOFRESSURED-GEOTHERMAL WELLS

DETAILTO REENTRY PFOGMOS IS FOR GEOPRESSLRE-GEOTHERMAL TESTING OF

STATE LEASE 4183 NO. " $\mathrm{WELL}$

GEUY FSOERA

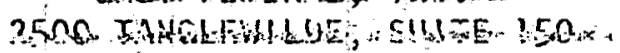
ICUSION, TEXAS 77063

$713 / 735-9 ? 00$

vulit 16, 1978

PSEPARED FCK THE

BEHARTHENT OF EHERT:

DIVISIDA OF' 'GECTHERYAI ENERGY

LAIEES CENTEACT EG-7;-r.-08-15:8

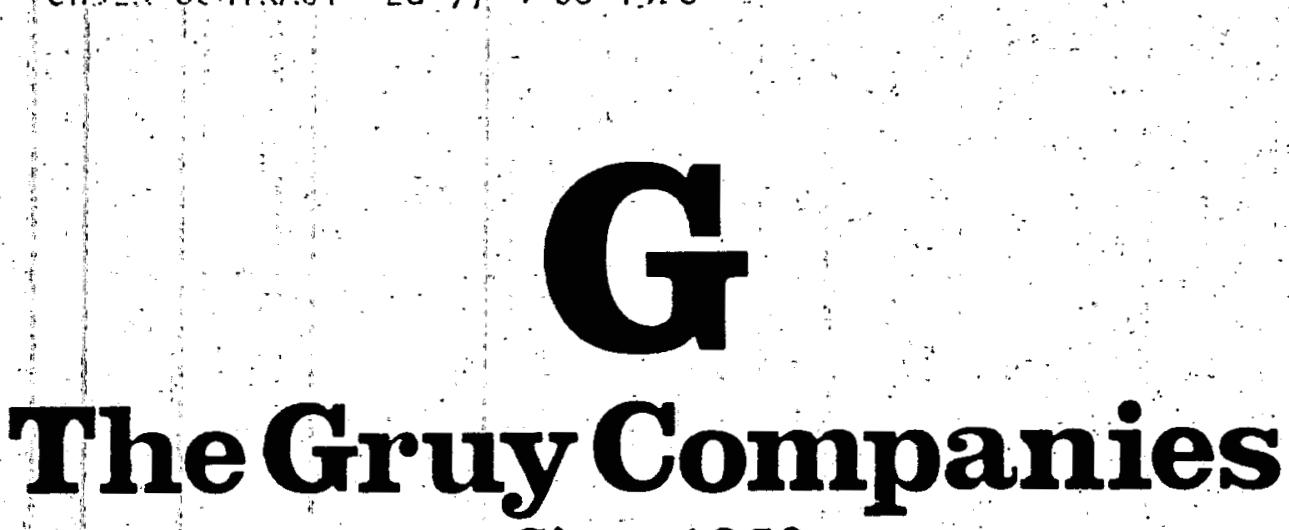

....Since 1950 


\section{DISCLAIMER}

This report was prepared as an account of work sponsored by an agency of the United States Government. Neither the United States Government nor any agency Thereof, nor any of their employees, makes any warranty, express or implied, or assumes any legal liability or responsibility for the accuracy, completeness, or usefulness of any information, apparatus, product, or process disclosed, or represents that its use would not infringe privately owned rights. Reference herein to any specific commercial product, process, or service by trade name, trademark, manufacturer, or otherwise does not necessarily constitute or imply its endorsement, recommendation, or favoring by the United States Government or any agency thereof. The views and opinions of authors expressed herein do not necessarily state or reflect those of the United States Government or any agency thereof. 


\section{DISCLAIMER}

Portions of this document may be illegible in electronic image products. Images are produced from the best available original document. 


\section{GRUY FEDERAL, INC.}

Consultants in ENERgy Systems

June 16,1978

2500 Tanglewilde Suite 150

HOUSTON. TEXAS 77063

$713 / 785-9200$
1911 Jefferson Davis Hwy. Suite 500

ARLINGTON, VIRGINIA 22202

703/9200113

Mr. Ronald T. Stearns

Engineering and Construction Division

DOE/Nevada Operations Office

P. 0. Box 14100

Las Vegas, Nevada 89114

Re: Contract No. EG-77-C-08-1528

Geo 2 Prospect L-5 - State

Lease 4183 No. 1

"Wells of Opportunity" Program

Dear Mr. Stearns:

As a further step in the Gulf Coast geopressured-geothermal "Wells of Opportunity" program, we hereby transmit the second revision of the reentry and testing recommendation for the Geo ${ }^{2}-L-5$ well in Cameron Parish, Louisiana.

The Gruy Federal, Inc. Geo ${ }^{2}$ L-5 well was originally drilled as the Pan American Petroleum Corporation (now Amoco Production Company) Well No. 1 State Lease 4183 in the Little Pecan Lake Area.

This package is complete in that all plats and $10 \mathrm{~g}$ sections are included and it will not be necessary to refer to previous submittals.

Attention is called to the discussion concerning certain items or "fish" left in the hole upon abandonment, a fact which was only revealed when we were permitted to examine Amoco's records on June 9, 1978. We have discussed this condition with no fewer than five experts in the field of fishing tools and all agree that the removal of junk should not present any unusual problems. They consider the fishing jobs to be "routine".

As of this date the permits from the State of Louisiana are expected in a matter of several days only. The time required to obtain Amoco's concurrence is conjectural. An educated guess is from two to four weeks unless an additional attempt is made to expedite Amoco's decision.

RJD:js

Yours very truly,

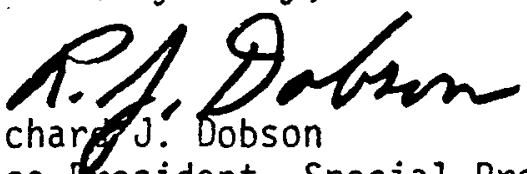

Vice President, Special Programs 


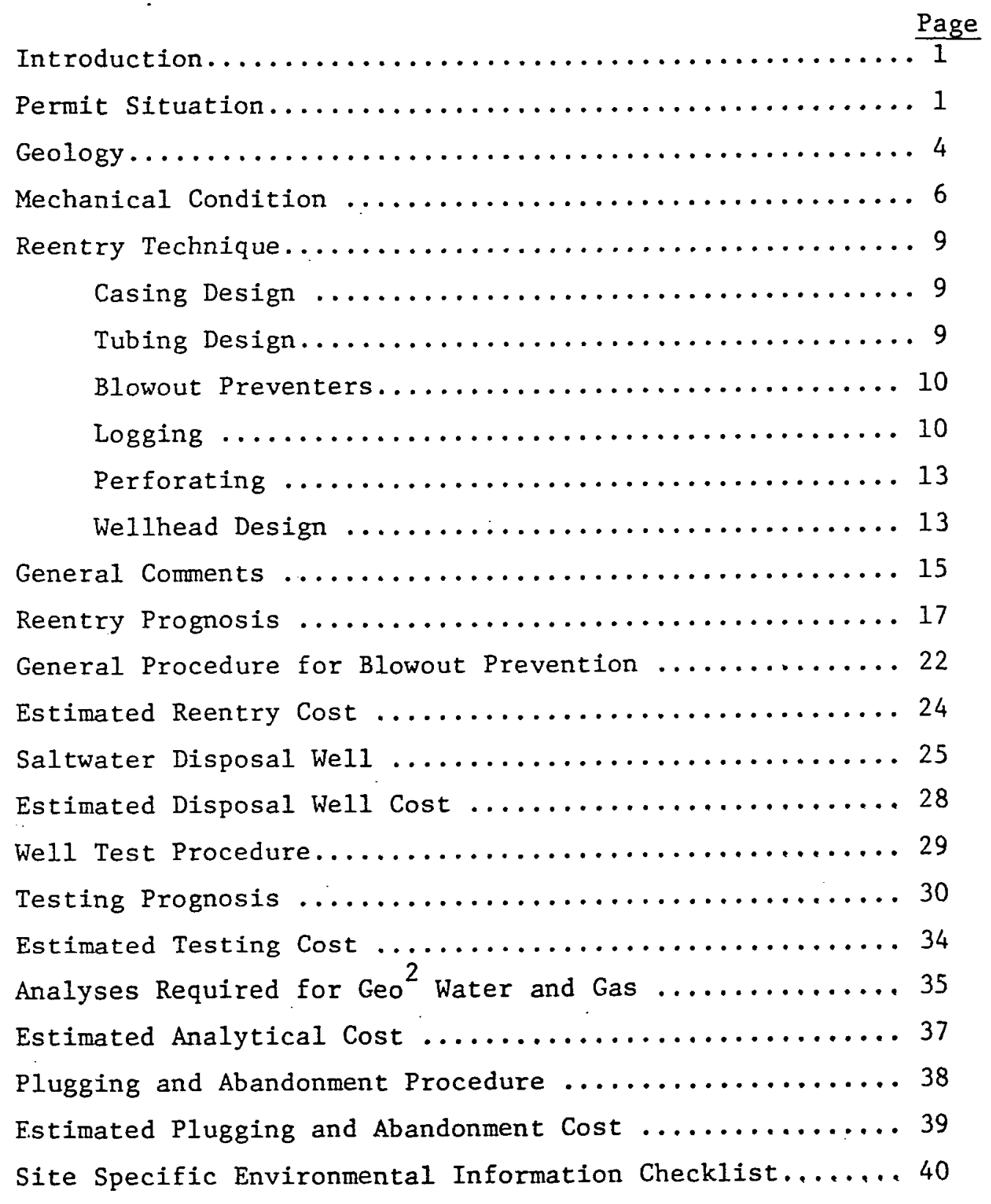


GRUY FEDERAL, INC.

\section{LIST OF FIGURES}

\begin{tabular}{llc} 
Figure & Item & Page \\
\cline { 2 - 3 } I & Location Map & 2 \\
II & Plat Showing Existing Road & 3 \\
III & Structure: Contoured on 15,400 & \\
& Foot Geo ${ }^{2}$ Sand & 5 \\
IV & Current Status versus Proposed & 7 \\
V & Completion & 11 \\
VI & Bottom Hole Tubing Assembly & 12 \\
VII & Blowout Preventer Design & 14 \\
VIII & Geo 2 Christmas Tree & 33
\end{tabular}


NV0/1528-9 A

\author{
GEOPRESSURED-GEOTHERMAL REENTRY PROSPECT L-5 \\ LITTLE PECAN LAKE AREA \\ CAMERON PARISH, LOUISIANA
}

Introduction

This Gruy Federal Type III-A geopressured-geothermal (GEO ${ }^{2}$ ) prospect was drilled as the Pan American Petroleum Corporation (now Amoco) No. 1 State Lease No. 4183, serial No. 1702399670. The well was abandoned in February 1970. It is 1ocated 1,200 feet north and 2,300 feet east from the southwest corner of Section 27, Township 15S, Range 4W. The location is shown on the U.S.G.S. topograhic sheet "Hog Bayou", a portion of which is included as Figure 1 . The well is accessible by lease roads off State Highway No. 82. A location plat is included as Figure II.

This $G^{2}{ }^{2}$ prospect is located on State land within the Rockefeller Wildlife Refuge and Game Preserve. The oil and gas leasehold rights are held by production from another well owned and operated by Amoco Production Company and other joint partners.

\title{
Permit Situation
}

Under Louisiana law, the geothermal rights including geothermal leasing rights, are held by the State and have been severed from oil and gas rights. Amoco Production Company holds no geothermal rights under its lease with the State. However, Amoco owns and controls the road system and the reentry rights to any nonproducing well which it has drilled so long as the well is located on a valid lease held by Amoco. Additionally, Amoco has a vested interest in the protection of its oil and gas rights. It is evident that even though Amoco does not control 


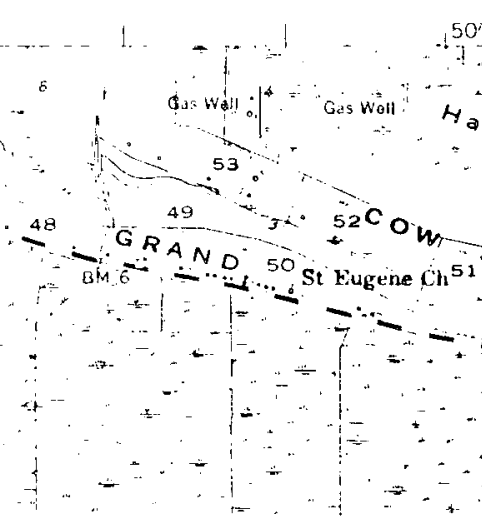

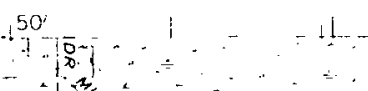
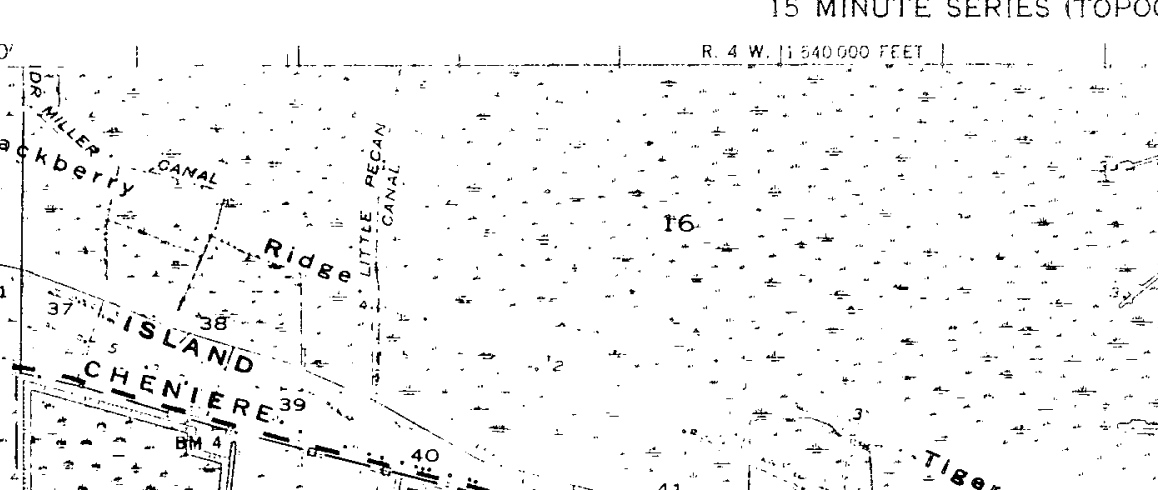

GETTY \& BUTTES GEO CO.

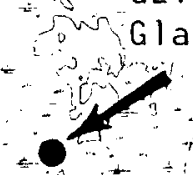

dys McCall No. I

$=0$

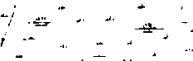

Bay

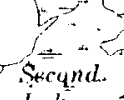
Stcumd.
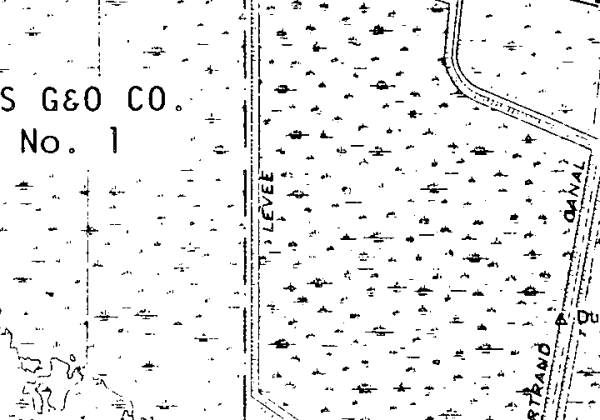

$\rightarrow B M-D-10+0$
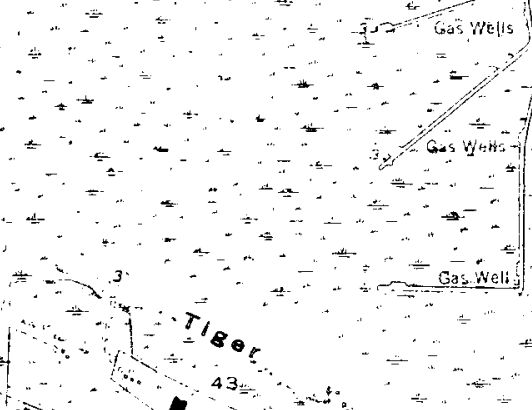

$27^{2}+45$

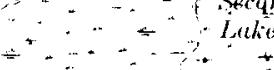

AMOCO

AMOCO $\overrightarrow{2}$
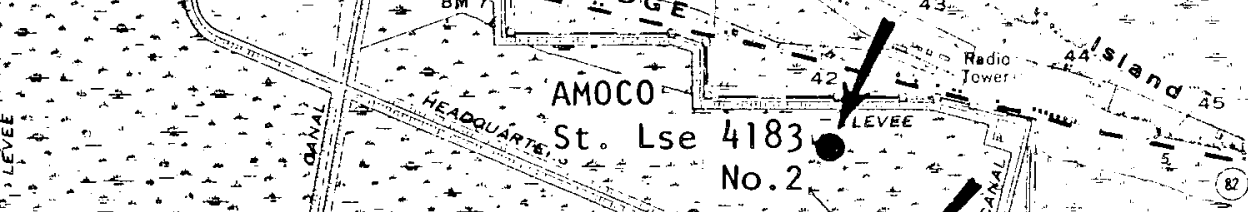

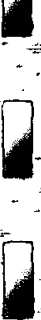

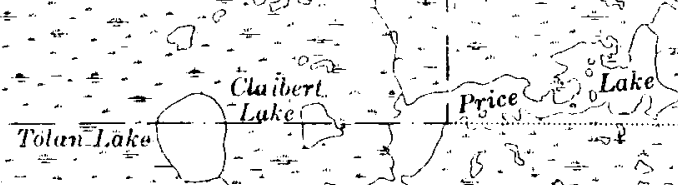

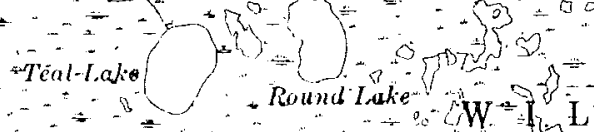

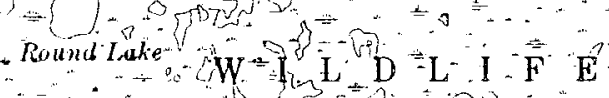

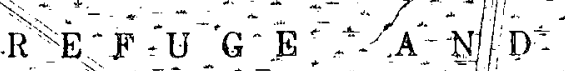
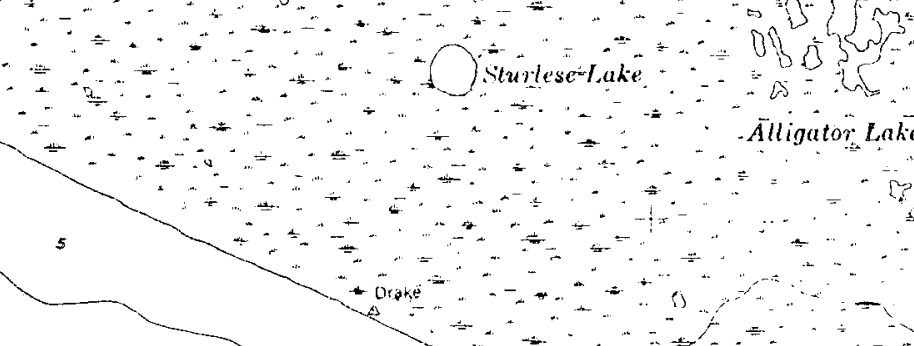

Alligator Late
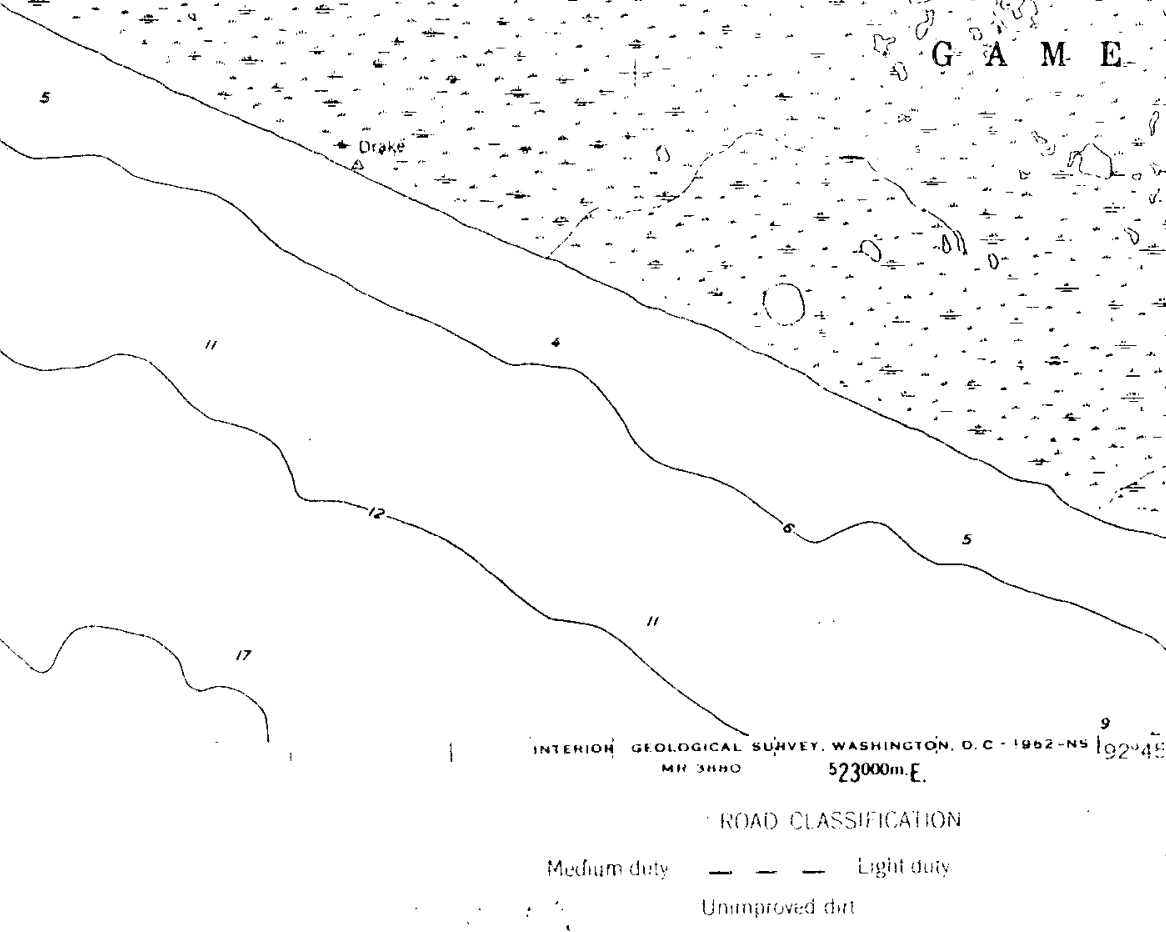

Shate icule: 

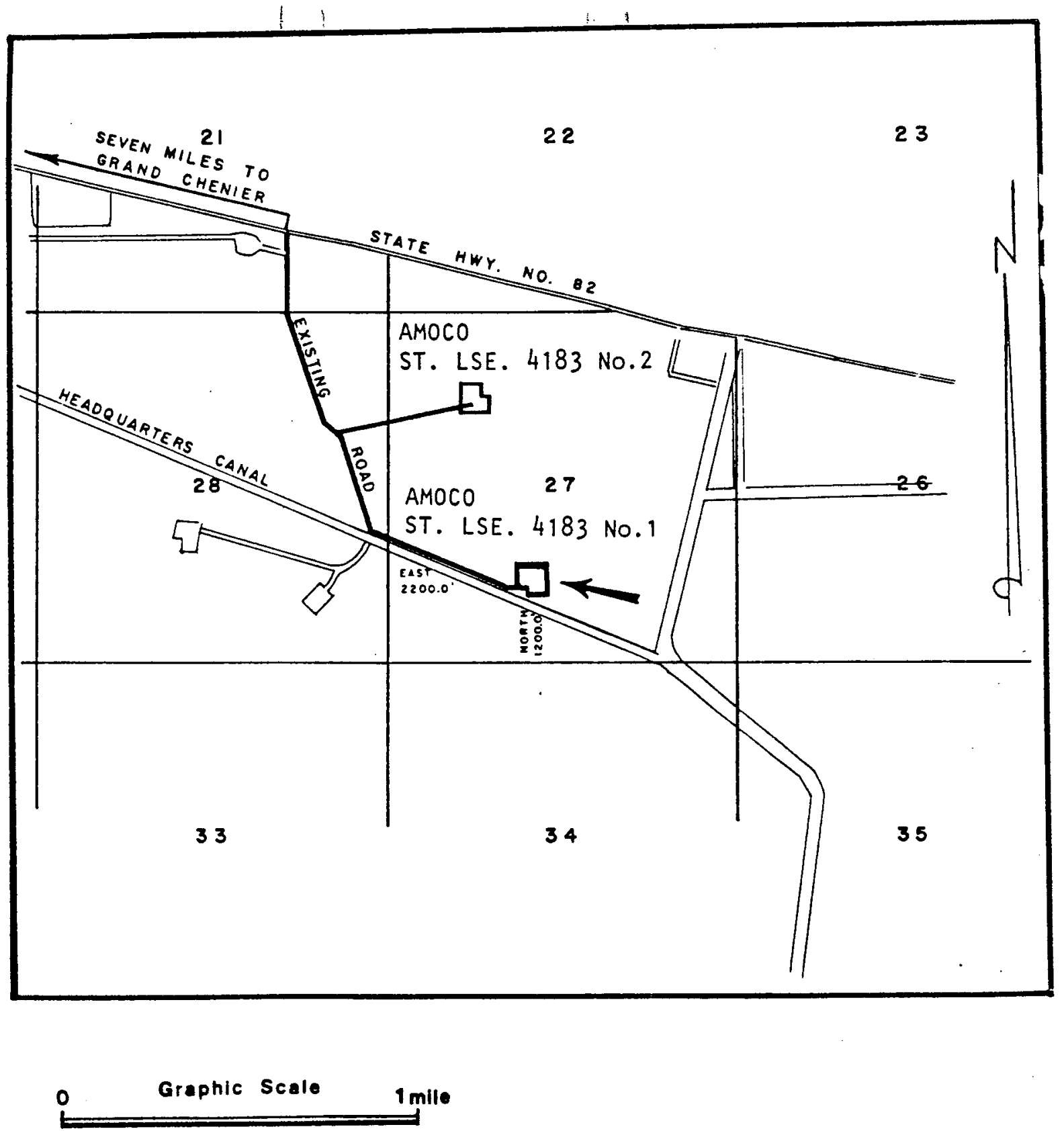

\section{GRUY FEDERAL, INC. Houston, Texas}

Little. Pecan Lake Area Cameron Parish, Louisiana

PLAT SHOWING EXISTING ROAD FROM STATE HWY. NO. 82 TO WELL LOC. AMOCO-State Lease 4183 No. 1

IN SEC.27, T.15S., R.4W 
NV0/1528-9A

the geothermal rights it is necessary to obtain Amoco's concurrence and cooperation to any Geo ${ }^{2}$ test program conducted on its lease or in a well controlled by that company and its partners in that venture (Mobil, Ashiand and Felmont).

Gruy Federal has applied for all necessary permits from state and local commissions and authorities. The Department of Natural Resources has taken an active role in expediting the issuance of permits and on June 15 assurance had been received that a11 necessary approvals would be in hand during the week of June 19.

Amoco Production Company has agreed, as of June 6, 1978, to consider the Gruy Federal request for permission to use its road system and other facilites and to discuss the matter with its partners. They have given no indication as to when or how they will respond to the Gruy Federal request, except to indicate that the matter is being expeditiously handled.

Geology

Figure III is a structural interpretation of the top of the $\mathrm{GeO}^{2}$ sands. The well site is shown to occupy a fault block of at least 3,000 acres on the downthrown side of a major fault of approximately 600 feet displacement. Although this is a highly faulted locality, the drainage area of the test well appears adequate for the proposed test.

The primary potential Geo ${ }^{2}$ aquifers penetrated by this well are from 15,575 to 15,740 feet and from 16,200 to 16,385 feet having net sand thicknesses of 70 and 125 feet respectively. The sand proposed for testing is the deeper of these aquifers; however, the completion design will enable both sands to be perforated and tested simultaneously. Both 


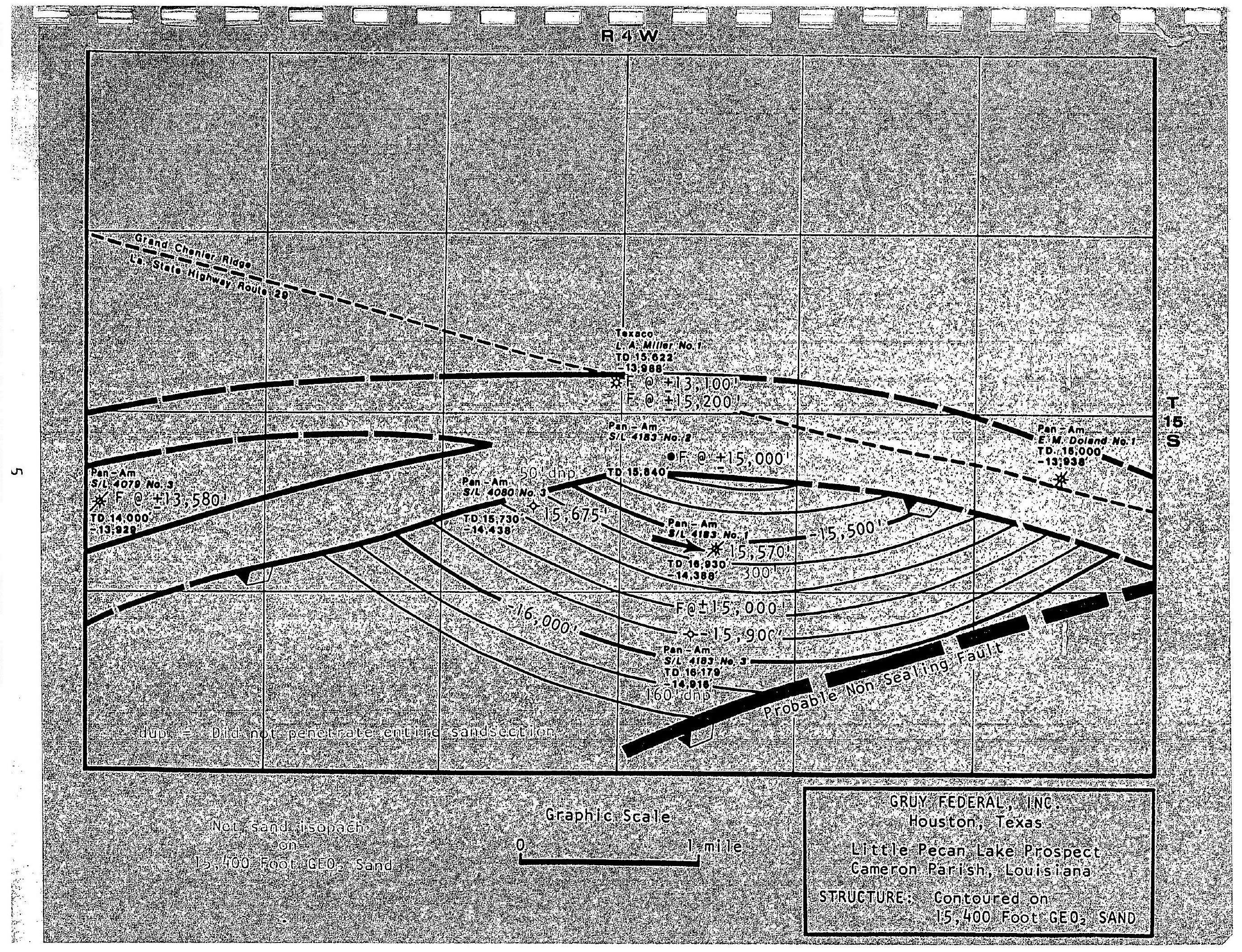


NV0/1528-9A

of these zones are of lower Miocene age and have no apparent show of hydrocarbons on the logs. The apparent degree of mud filtrate invasion suggests a permeability of something in the lower magnitude of that normal for Miocene sands. During drilling operations through these sands, a mud weight of $17.2 \# / g a l l o n$ was used. This would indicate that the static aquifer pressure at 16,300 feet is approximately 13,575 psia (assuming 1,000 psi overbalance of the mud column). The maximum recorded temperature from the electric $\log$ is $305^{\circ} \mathrm{F}\left(152^{\circ} \mathrm{C}\right)$ which would indicate an aquifer temperature of $328^{\circ} \mathrm{F}\left(164^{\circ} \mathrm{C}\right)$ based upon correction factors for log temperatures developed for South Louisiana by A.A.P.G.

Mechanical Condition

Figure IV illustrates the present condition of the well and the proposed condition for testing. Information on the present condition was obtained from Amoco well records and those of the contractor who abandoned the well and salvaged portions of the tubing and 7" and 9-5/8" casing. These differ in detail from the plugging and abandonment reports filed with the Louisiana Department of Conservation.

Amoco records indicate that the $9-5 / 8$ " casing was cut with a chemical cutter and subsequently shot with a dynamite charge at 2,800,2,700 and 2,400 feet in unsuccessful attempts to recover casing before being successfully cut and pulled at 1,000 feet. Thus it will be necessary to run a tapered mill to check for any distortion or displacement at the shot points. Since a full string of 7 " casing will be tied to the existing cut-off 7" casing it will only be necessary to insure passage of drill pipe with bit and subsquently the $7 "$ casing. The 9-5/8" casing will not be subject to formation pressure. 


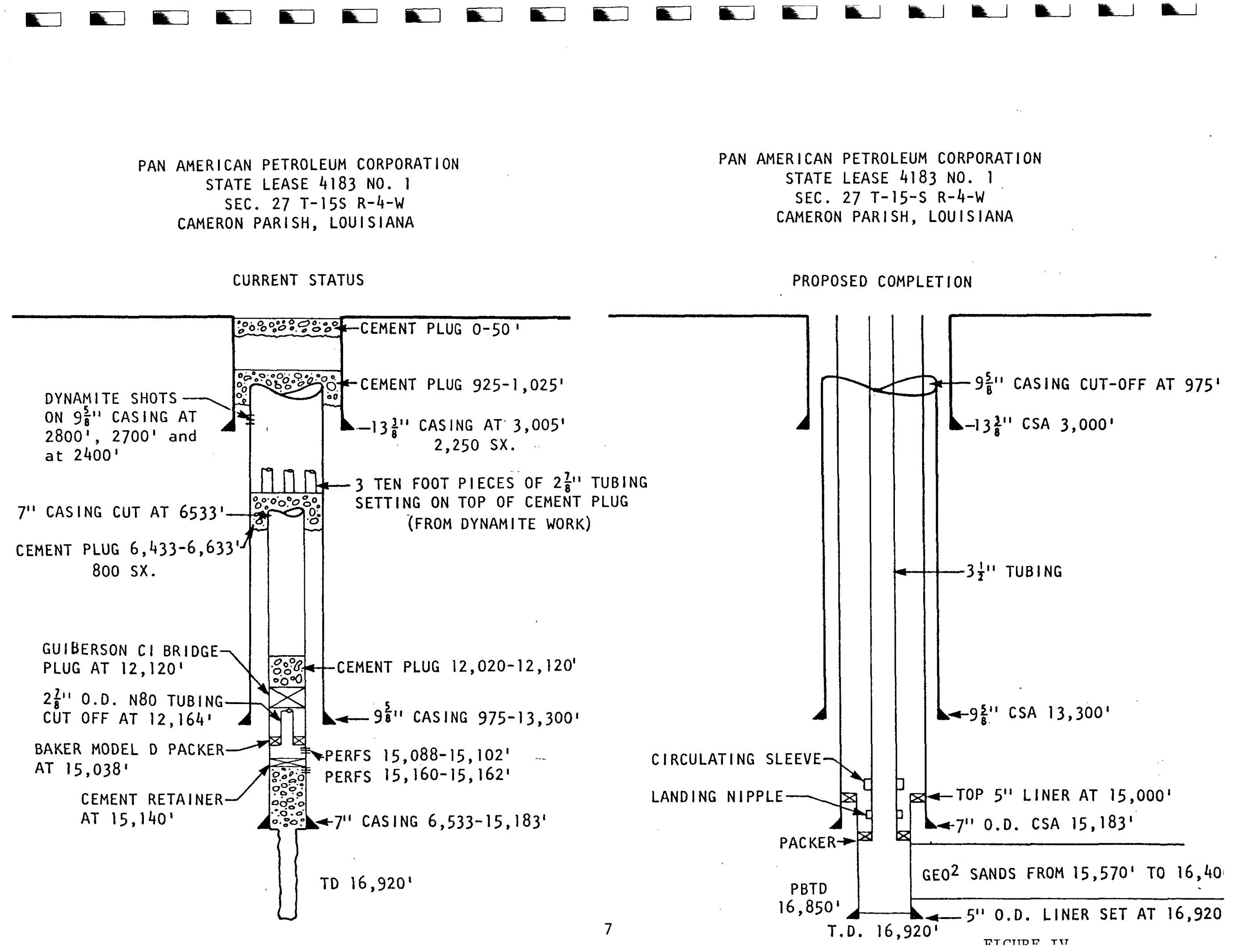


NV0/1528-9A

The second step in reconditioning will consist of the recovery of three sport pieces (10-12 feet) of 2-7/8" OD tubing which was used as weight to lower each dynamite charge when the 9-5/8" casing was shot. These are located within the 9-5/8" casing, presumably on the cement plug which covers the top of the $7 "$ casing. Consultations with a number of experienced fishing tool operators have resulted in the unanimous opinion that recovery of these items can be accomplished in a routine manner by standard fishing tools.

The next step will consist of drilling the cement plug which was placed above the top of the 7" casing at the point at which it was cut and recovered. After the top of the $7 "$ casing is dressed, a new tieback string of 7" casing with appropriate tie-back mechanism will be run.

After the full string of $7 "$ casing has been tied back and pressure tested it will be necessary to wash over and recover the remaining 2,899 feet of 2-7/8" OD tubing which is currently mud stuck. Information on the condition of the tubing which was recovered when the well was abandoned is to the effect that there was no corrosion or unusual wear on the pipe. Thus the recovery of the remaining tubing is expected to be a routine fishing operation.

The necessity for cleaning the well of this foreign matter and rolling out the 9-5/8" casing is expected to require 5 to 7 days of additional rig time and to increase the cost over a normal "clean" reentry by an estimated $\$ 75,000$.

After the recovery of the above described "junk", it will be necessary to squeeze and test the existing perforations at 15,088 feet to 15,102 feet and 15,160 feet to 15,162 feet, following which the open 
NVO/7528-9A

hole will be cleaned out to a depth sufficient to run and cement a 5 " liner through the objective Geo ${ }^{2}$ sands.

\section{Reentry Technique}

A detailed reentry and recompletion prognosis is attached. In designing the equipment and specifying the procedures, the primary consideration was the safety of the operation and the experience of prudent operators who have successfully penetrated and produced from geopressured-geothermal gas reservoirs in the Louisiana Gulf Coast.

Casing Design

Since only a 6,533 foot tie-back string of 7" $0 D$ casing is required, it was impractical to design a graded casing string. In order to accomodate the tensile load of hanging the casing in tension, P-110, 38\#, long thread and collar has been specified.

\section{Tubing Design}

The tubing design selected consists of a tapered string of 2-7/8", 8.70\# P-105 from the Intracoastal City inventory to run inside the 5" OD casing liner and $31 / 2^{\prime \prime}, 12.70 \#, P-105$, PH6 Hydril threaded tubing. If this well is chosen as the first reentry, the existing DOE 3-1/2" tubing in inventory will be utilized.

The 2-7/8" OD tubing is necessary to enter the 5" OD liner and still allow clearance for the tubing gun to pass through the seal assembly and landing nipples. The portion of the tubing which seats in the packer will be equipped with a seal assembiy to allow for approximately 
NV0/1528-9A

10 feet of expansion and contraction during flowing and plugging operations. A landing nipple and a circulating valve will be placed above the seals to permit communication between the tubing and casing. Figure $V$ is a diagram of the bottom hole tubing assembly.

\section{Blowout Preventers}

The well prognosis sets out the necessary safeguard specifications and procedures for surface blowout prevention as they have been adopted by IADC, API and prudent operators in the $\mathrm{GeO}^{2}$ areas. A diagram of the BOP hookup and choke manifold assembly which is proposed is shown as Figure VI.

\section{Logging}

The reentry prognosis recommends that the following open hole logs be run:

(1) Induction electric log

(2) Compensated neutron and compensated density logs

(3) Caliper

(4) Sonic

Although an induction electric $\log$ and a sonic $\log$ have been run previousiy, these logs should be rerun in order to evaluate any invasion which has occurred since the well was completed initially. No sidewall cores are recommended in order to avoid any possible mechanical hole problems. The cased hole logs; namely, the gamma ray, cement bond and collar locator, are desirable to establish the integrity of the cement and as a benchmark for perforating. 


\section{PAN AMERICAN PETROLEUM CORPORATION \\ STATE LEASE 4183 NO. I \\ SEC. 27 T-15-S R-4-W \\ CAMERON PARISH, LOUISIANA}

BOTTOM HOLE TUBING ASSEMBLY

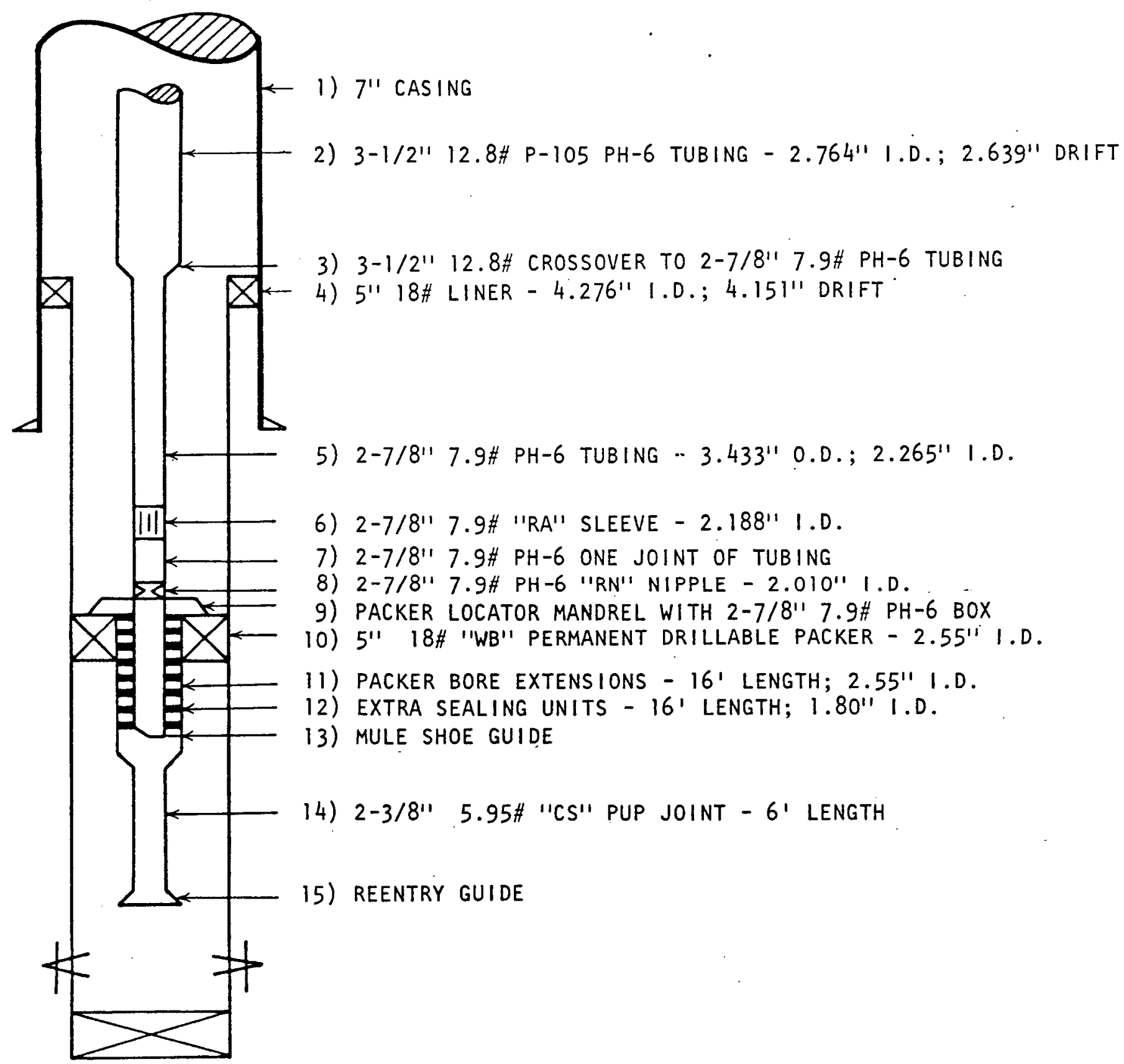




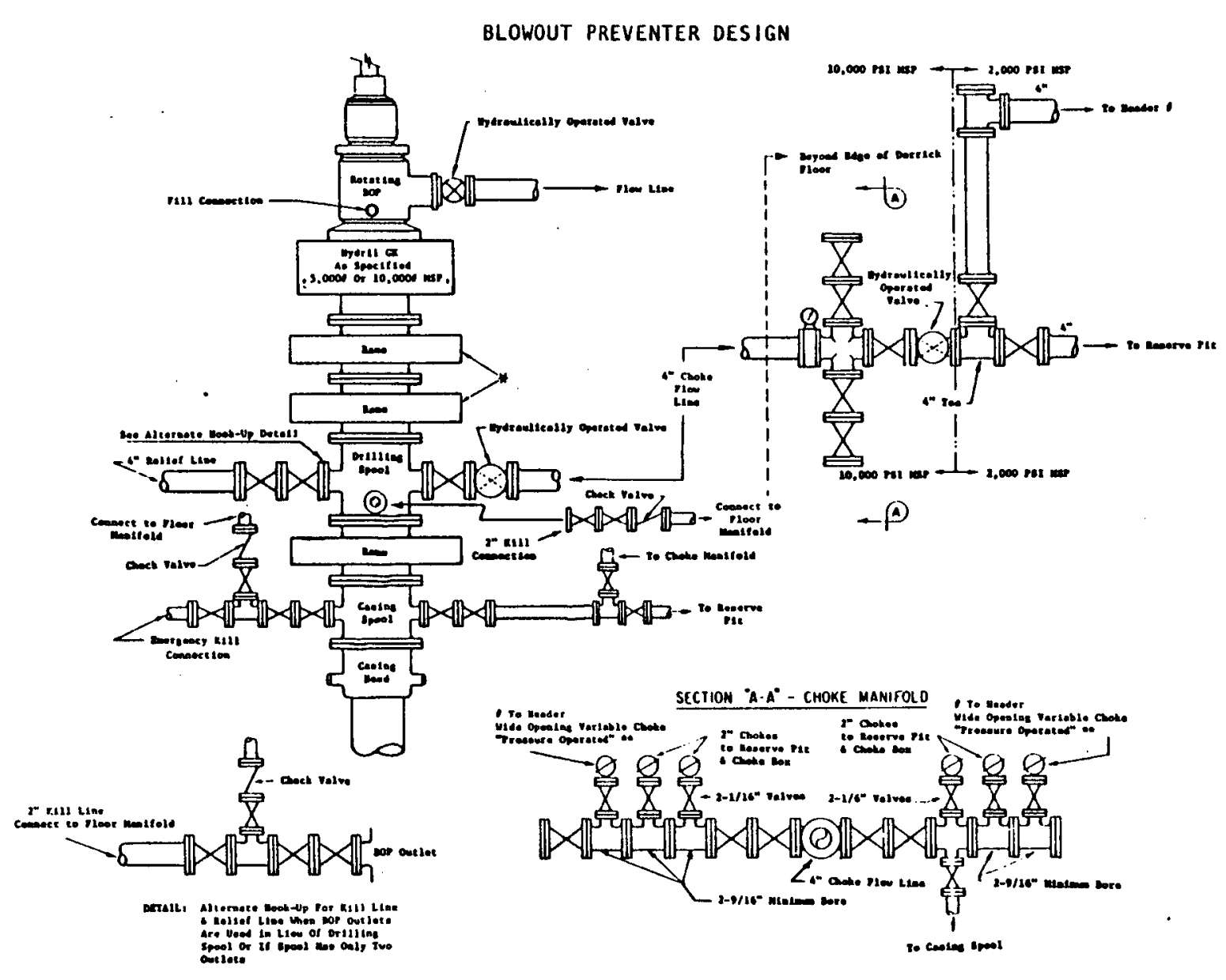

Minimum operat ing equipment for preventere will be at follows: (1) multiple pumps, driven by - continuous eource of power capable of fluid charging the total eccumuletor volube within twenty winutes; and (2) eccunulators with a pre-charge of nitrogen at not leas than 750 pal and capable of recelving a fluld charge fros the (charging) pumpa. Fiuld charge voluae ohall be the amount required to incrases accumulator preasure frow nitrogen pre-charge pressure to rated pressure. Charging pumpe are to be connected to the hydraurequested in additlonal remote end equivelent cource of pover shoil be avalleble to operate the puape. The presour ized fluid volume atored in the occumulators shell be sufflcient to close all pressure operated devices eimulteneously within 20 seconds with charglng pumps shut down. Minimu accuaulator presaure shall be 1500 pal Initially and not laes than 1200 pai when ell preventore are closed.

The closing aenifold and remote clooing mentfold (flooroperated device. which pressure device tt controls and to ehou open and closed posirtons. A pressure reducer and regulator it to provided for the Hydril GK. Hydraultc oll ahall be used as the operating tluid. One-inch size seanleos ateel piping shall be weed to connect the closing unit to the preventors. Pipling is to be cested to anxioum reted pump premeure. The choke manifold, the four-1nch choke flowline and the fourInch rellef line shall be aupported by metel atande or ralogharp bends or curves will be peralitted to the chake tlows IIne fron the preventera to the plte. Header to beve throe way outlet: (1) to reaerve pit, (2) to choke box, (3) to meparator. Easy and safe access vill be mintalped to the choke manifold. If deemed necessary, ualkuay: and atainuye vill be provided in and around choke wanlfold. All valves throughout the assembly whall be welected for operation in the presence of oll, ass and drilling hulds. Valves connected adjacept to the drilling opool and all ras-type Jolets if needed, and operet ing theele unteh ar to extend beyond edge of derrtck oubetructure. Any other velves within the 1lmite of the derrick subetructure will bo equipped when requeeted. 
NV0/1528-9A

\section{Perforating}

The perforating will be accomplished with a 1-11/16" high-temperature, through tubing jet perforating gun with four shots per foot and zero phasing. When fired this jet creates a casing entry diameter of approximately 2" beyond the cement sheath. Assuming 100 percent firing efficiency, this configuration should provide a productivity equal to 70 percent of the open hole productivity.

In selecting the fraction of the net sand to perforate, the perforated interval length was designed to achieve a productivity equal to $1 / 3$ of the open hole productivity. In the State Lease 4183 No. 1 well, this productivity can be accomplished by perforating approximatily ?? feet. The final interval will be contingent upon the analysis of the additional open hole logs that will be run.

The well will be perforated with $\mathrm{CaCl}_{2}$ water in the hole so that a pressure differential from the formation to the well bore will exist. When the first gun is fired, water from the formation will expand into the well bore and equalize the pressure on both sides of the casing. Perforating in this manner will prevent mud filtrate from entering the formation with a simultaneous buildup of mud cake on the wall of the perforation.

\section{Wellhead Design}

Figure VII is a sketch of a Geo ${ }^{2}$ christmas tree which has been designed by the WKM WELLHEAD SYSTEMS DIVISION. The tree is rated to a working pressure of 10,000 psi. All valves have T-24 steel vertical runs with packing and seals for high temperature fluids $\left(360^{\circ} \mathrm{F}\right)$. The 

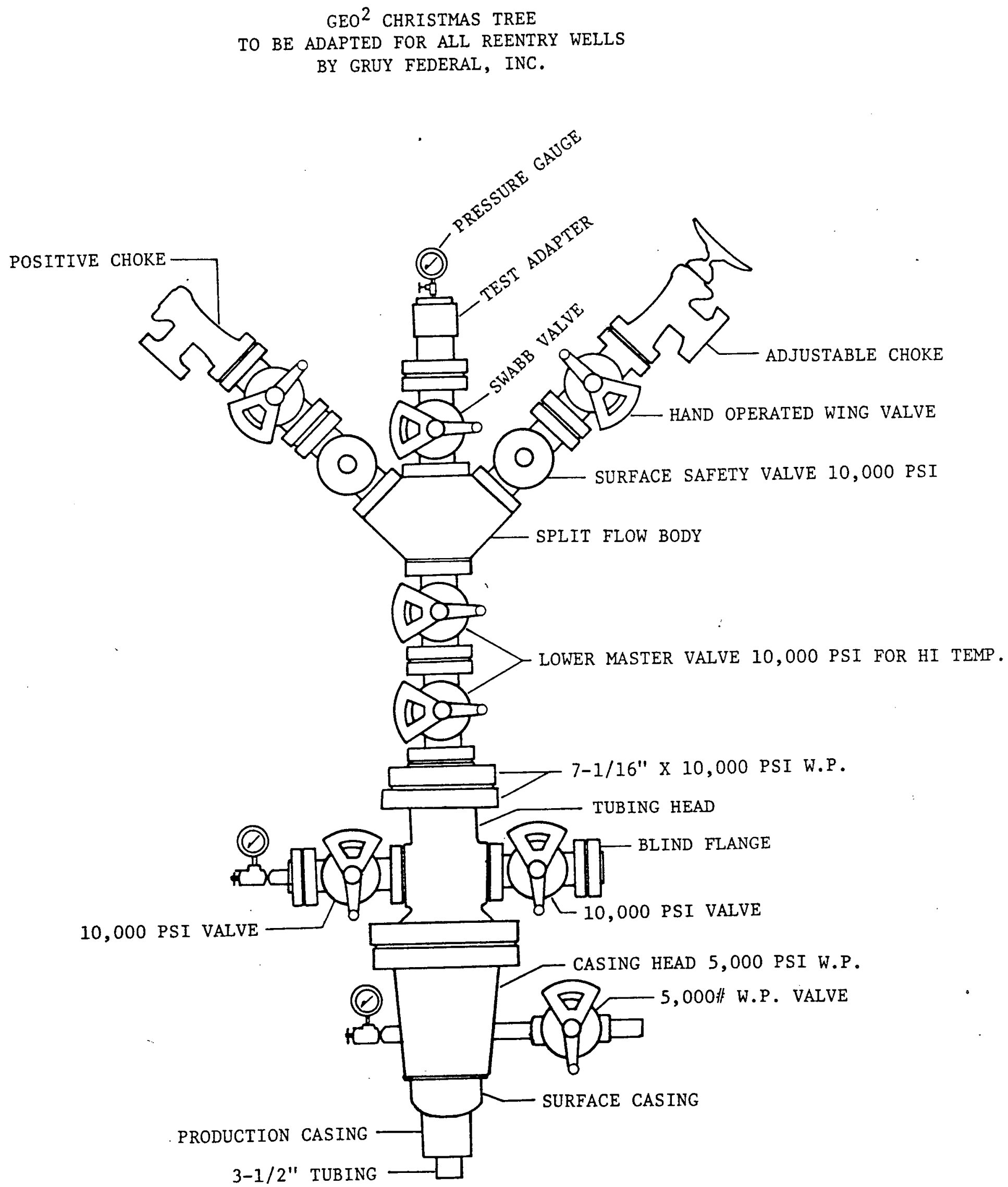
NV0/1528-9A

tree consists of two 3-1/16" master gate valves and a 3-1/16" swab valve. Between the master gate valve and the swab valve is a double wing assembly to house the choke bodies. One wing will contain a positive choke and the other will contain an adjustable choke. Each wing will consist of a Hi-Lo safety valve and a conventional wing valve. This specific design limits the anticipated high pressures to the tree assembiy.

During squeeze cementing to plug and abandon the well, the wellhead pressure may exceed 10,000 psi. To overcome this problem it is planned to utilize a wellindad isolation tool developed by Halliburton. The tool is attached to the top of the swab valve on the tree and a mandrel is hydraulically positioned through the master gate valves until it is locked in the production tubing. This device, rated at 20,000 psi working pressure, isolates the wellhead from the treating fluid pressure. The tubing in the well will accomodate all anticipated pressures.

The casinghead used to set the production string has been designed to accept any casing size of all the wells under consideration and be compatiole both with the blowout preventers and the upper christmas tree assembly.

\section{General Comments}

The State Lease 4183 No. I well has been recommended as a $\mathrm{GeO}^{2}$ candidate for the following reasons:

(1) The well is located in a recognized geothermal fairway which has been identified by the Petroleum Engineering Department of LSU under contract to DOE. 
NV0/1528-9A

(2) The geopressured objective sand has the highest indicated temperature $\left(328^{\circ} \mathrm{F}\right)$ of any available candidates which have been screened.

(3) Available data indicate that the Geo ${ }^{2}$ sections are capable of producing salt water in sufficient quantities for the scheduled test period.

(4) Modern logging equipment can be run in the open hole interval of interest and sidewall core sampling may be possible.

(5) The site can be prepared in a maximum of 10 to 14 days from the time all clearances are received. 
GRUY FEDERAL, INC.

NV0/1528-9A

WELL PROGNOSIS

FOR

PAN AMERICAN PETROLEUM CORPORATION

STATE LEASE 4183 N0. 1

LITTLE PECAN LAKE AREA

Operationa 1

Day

1. Prepare location.

2. Dig out and inspect 13-3/8" surface casing, extend to proper elevation and weld on casinghead.

1st 3. Move in rig, rig up and install BOP's.

4. Clean out 13-3/8" OD casing with 12-1/4" OD rock bit to the top of the cut-off 9-5/8" 00 casing at approximately 1,000 feet. Run 12-1/4" rock bit, 6-1/2" OD dri11 collars, 3-1/2" OD drill pipe. Pull out of hole.

4th 5. Run 11-1/2" OD lead impression block on bottom of 6-1/2" OD drill collars and 3-1/2" OD drill pipe. Pull out of hole.

6. If required from appearance of lead impression block, run 8-3/4" OD long tapered carboloy junk mill to dress out top of cut-off 9-5/8" OD casing. Dress out top to permit working through to top 7" OD casing. Run mi11, 6-1/2" OD dri11 collars, 3-1/2" OD drill pipe. Pull out of hole.

7. Clean out $9-5 / 8$ " OD casing with $8-3 / 4$ " OD rock bit to the top of the junk above the cut-off 7 " OD casing. 
GRUY FEDERAL, INC.

NVO/7528-9A

5th 8. Run 8-5/8" wash pipe with junk catcher and carboloy rotary shoe and retrieve junk tubing.

9. Drill cement to top of 7" casing at approximately 6,533 feet.

10. Run $8-1 / 2^{\prime \prime}$ OD lead impression biock on bottom of $6-1 / 2^{\prime \prime}$ OD dri11 collars and 3-1/2" 00 drill pipe. Pull out of hole.

11. If required from appearance of lead impression block, run 6" OD long tapered carboloy junk mill to dress out top of cut-off $7 "$ OD casing. Run mill, 4-1/2" OD drill collars, 3-1/2" OD drill pipe. Dress out top of cut-off 7" OD casing and clean out approximately 75 feet below top of cut. Pull out of hole.

12. Go in hole with two joints 8-5/8" OD 36\# Hyd. FJWP washover pipe; $8-3 / 4$ " OD tooth type carboloy rotary shoe, top bushing, and 4-1/2" API IF Johnston hydraulic oil jars on bottom of 6-1/2" OD drill collars and 3-1/2" OD drill pipe. Wash over approximately 60 feet of the $7 "$ OD casing. Pull out of hole.

6th 13. Go in hole with hydraulic pressure operated mill dressed to cut 7" OD casing. Run on bottom of 4-1/8" OD drill collars and 3-1/2" OD drill pipe. Locate first casing collar using minimum pressure/slack-off technique, sliding cutter downhole until cutter knives catch in joint and cutter stops moving down-hole. Bleed pressure, drop 5 feet to 10 feet below collar and make inside cut. Mill approximately 6" of the 7" OD casing to dress top smooth for external casing patch. Pull out of hole. 
NV0/1528-9A

7th 14. Go in hole with 7" casing spear, 3 foot extension, 7-1/4" OD stop sub, bumper jars, and hydrautic oil jars on bottom of 4-1/8" OD drill collars. Retrieve fish. Pull out of hole.

15. Go in hole with external casing patch on bottom of 7" 00 38\# P110 LT\&C casing and tie casing together.

16. Nipple up 7" casing.

17. Continue in hole to top of cement plug at 12,020 feet and test casing above this point to 7,500 psi. Repair casing or tie back if necessary by cement squeeze.

9th 18. Condition mud to $17.2 \#$ /gallon then dri1l cement from 12,020 feet to 12,120 feet and the cast iron bridge plug at that depth.

10th 19. Circulate and continue in hole to top of 2-7/8" OD N-80 tubing cut off at approximate $1 y$ 12,164 feet. Condition mud and pull out of hole.

11 th 20. Go in hole with overshot and 500' of wash pipe and wash over 500 feet of fish. With a wireline chemical cutter, make an inside cut on the tubing just below the bottom of the overshot and recover fish.

13th 21. Go in hole with overshot and 2,500 feet of wash pipe and wash to top of Baker Model D packer at 15,038 feet. Circulate and condition mud. Unseat tubing from packer and recover. 
GRUY FEDERAL, INC.

NV0/1528-9A

15th 22. Make trip in hole with burn shoe and packer recovery device to top of packer at 15,038 feet. Burn over packer slips until they release and spear seats in packer. Pul1 packer.

16th 23. Continue in hole to the current plug back total depth of approximately 15,170 feet and condition mud.

24. Make trip and run retrievable squeeze tool. Set same at about 15,050 feet and squeeze cement existing perforations from 15,088 feet to 15,102 feet and from 15,160 feet to 15,162 feet to a maximum and final pressure of 7,500 psi; then reverse out excess cement.

17th 25. Lay down squeeze tool and go in hole with bit. Drill out retainer at approximately 15,170 feet, then wash and ream old 6-1/16" hole to original total depth of 16,920 feet or at least to a depth of 16,600 feet and condition hole.

26. Run IES electric $\log$ and Compensated Neutron and Density logs.

20th 27. Rig up and run 1,920 feet of $5 "$ OD 18\# P110 FJ casing to total depth of 16,920 feet and cement with sufficient cement to circulate the full annular space behind the liner. The liner is to be equipped with a casing shoe on bottom, a float collar two (2) joirts above bottom and with centralizers on each joint of casing opposite the interval from 15,500 feet through 16,400 feet.

21st 28. Pick up 2,000 feet of 2-7/8" work string and go in hole to the float collar on the $5^{\prime \prime}$ casing and condition hole. 
NVO/1528-9A

29. Rig up and run a gamma ray-cement bond log from total depth to about 15,000 feet and block squeeze, if necessary. Squeeze top of liner, if necessary.

23rd 30. Drill out cement and condition hole to plug back total depth of about 16,850 feet. Displace the mud in the hole with $10 \# /$ gallon $\mathrm{CaCl}_{2}$ water and observe the hole for back flow and pressure increase at the surface. If none occurs, lay down drill pipe.

24th 31. Rig up and set permanent packer at 15,500 feet inside 5" 1 iner.

32. Make up completion assembly on bottom of tubing (see enclosed drawing). Pick up 500 feet of 2-7/8" OD 8.7\# P-105 PH6 Hydri1 tubing and 15,000 feet of 3-1/2" OD 12.7\# P105 PH6 Hydril tubing. Space out tubing and set stinger with seals in packer. Pressure test the packer with 6,500 psi differential from the bottom and 5,000 psi from the top. Each joint of tubing is to be tested to 10,000 psi while going in the hole for completion.

33. Hang tubing with wrap-around hanger, remove the BOP's and nipple up the christmas tree. Test tree to 10,000 psi.

26th 34. Release rig and rig down.

28th 35. Finish moving out rig. Operations on $\mathrm{GeO}^{2}$ well suspended while disposal well being drilled. 
NV0/1528-9A

41st 36. Move in and rig up wireline lubricator on well and test same to 10,000 psi. Perforate the interval to be selected from the new logs obtained with four (4) shots per foot. Most likely, the interval will be within the sand occuring from 16,200 feet to 16,375 feet. This will require three trips with a tubing gun which covers 46 feet per trip. Since the initial perforating gun will be fired with a differential to the well bore, observation shall be made of the increased tubing pressure for leak off of static fluid pressure in the casing to make sure there are no leaks in the tubing or packer.

42nd. 37. Rig down wireline unit and connect the test unit for production tests.

GENERAL PROCEDURE FOR BLOWOUT PREVENTION:

1. Use BOP design as attached. The minumum assembly will consist of three preventers. The bottom and middle preventers may be Cameron QRC, Cameron Type $F$ or Shaffer Hydraulic Single, and the upper preventer will be Hydril GK. Double preventers or space savers may be used if approved by the company supervisor. An accumulator with a closing unit is required. Accumulator reservoir pressure shall be sufficient to close all preventers simultaneously in 20 seconds with the charging pumps closed down. Minimum accumulator pressure shall be 1,500 psi initially and not less than 1,200 psi when all preventers are closed.

2. When nippling up production casing, test BOP's and choke manifold to 7,500 psi with cold water, or as specified by the company representative. BOP's will be tested at least once each day thereafter when working in open hole and once each week otherwise. 


\section{GRUY FEDERAL, INC.}

NVO/1528-9A

3. Have a full opening safety valve and Grey inside BOP with drill pipe connections on the rig floor.

4. Have extra pipe rams on location at all times while drilling or completing.

5. Locate all choke manifolds, lines and valves at the side of and away from the substructure. Adequately support and tie down the choke assembly. 


\section{ESTIMATED REENTRY COST \\ for \\ STATE LEASE 4183}

\section{Activity}

Est.

Amount

1. Lease acquisition and legal fees

2. Rig transportation cost (Ist move to Cameron Parish, Louisiana)

25,000

3. Location preparation

72,200

4. Rig time -30 days at $\$ 6,000$

180,000

5. Bits

2,000

6. Mud and chemicals

40,000

7. Casinghead

2,000

8. Christmas tree, incl. surface safety controls

80,500

(1)

9. Casing patch, mills, equipment \& service

25,000

15,000

10. Rental tools and equipment

20,000

11. 3-1/2" drill pipe rental

10,000

15,000

13. Cement and services

37,600

14. Logging and coring

28,500

15. Perforating

500

16. $500^{\prime}$ of $2-7 / 8$ " P-105 4.7 非 PH-6 Hydril tubing

17. 5,930' of new 3-1/2" P-105 12.95 \# PH-6 Hydril tubing

121,600

18. $9,130^{\prime}$ of $3-1 / 2^{\prime \prime}$ P-105 12.95 \# DS tubing from stock

1,500

19. Packer and subsurface equipment

3,500

20. 6,600' of $7 "$ 'OD tieback casing per prognosis

127,200

21. $1,920^{\prime}$ of $5^{\prime \prime}$ OD 13 \#” $\mathrm{P}-110 \mathrm{~F} . \mathrm{J}$. liner

25,600

22. Supervision

7,500

23. Miscellaneous

20,000

24. Contingencies

45,000

25. Material handling $@ 1.3 \%$ of all except items 1 , $22 \& 23$

11,085

26. $G \& A \& 18 \%$ of items $1 \&: 22$

1,890

TOTAL

(1) Can be reused on alternate wells after minor shopping.

(2) Available from stock at Intracoastal City. 
GRUY FEDERAL, INC.

NVO/1528-9A

SALT WATER DISPOSAL WELL

FOR

PAN AMERICAN PETROLEUM CORPORATION

STATE LEASE 4183 NO. 1

LITTLE PECAN LAKE AREA

The available electric logs covering the shallow sands from the conductor pipe to a depth of 5,000 feet indicate that the fresh water sands extend to a depth of approximately 900 feet and that sands capable of accepting high flow rate salt water occur above 4,000 feet. Detailed electric logs on the specific well will isolate the exact sand to be perforated.

The basic design of the casing prugram coniorris with the requirements of the Department of Conservation. No tubing is recommended for the well because it acts to increase the surface injection pressure and would only be utilized if backflushing is required. The need for backflushing appears to be remote for the following reasons: (1) a volume of less than 200,000 barrels will be injected, (2) filters are provided downstream from the pumps to reduce solid and scale build-up, (3) the closed system prevents bacterial growth, and (4) two injection pumps (one of which is a standby) capable of delivering 10,000 barrels per day at an injection pressure of 500 psi.

In the event that formation plugging prevents disposal of the water, coiled tubing can be lubricated into the well and the sand backwashed using nitrogen. 
NV0/1528-9A

40th 11. Run gamma ray - cement bond log from total depth to 1,200 feet and block squeeze with cement if necessary to obtain good bond.

42nd 12. Rig down and move out water well rig.

13. Perforate approximately 50 feet of the lowest clean sand determined from electrical logs with four shots per foot using a casing bullet gun and rig down wireline unit.

14. Test injectivity of well with rig pumps or pump truck to achieve 10,000 barrels per day injection rate at $150 \mathrm{psi}$ or less. If injection rate is not sufficient, select and perforate additional sand interval or consider treatment with mud cleanout acid, or both, if deemed necessary. 
GRUY FEDERAL, INC.

NVO/1528-9A

\section{Operational}

Day

01 Drive 13-3/8" OD casing to refusal or \pm 125 feet.

29th 2. Move in and rig up water weil rig.

37st 3. uriil 12-1/4" hole to 1,200 feet.

32nd 4. Run 1,200 feet of 9-5:8" $35.0 \# \mathrm{H}-40$ casing with guide shoes on bottom and a float collar one joint above bottom. Use one centralizer per 100 feet of casing for bottom 500 feet and cement casing to surface.

34th 5. Drill 8-3/4" hole below surface casing to 4,000 feet.

36th 6. Run Induction Electric and Density logs and SWC if desired.

37th 7. Run 4,000 feet of 5-1/2" OD 15.5\# J-55 casing with guide shoe on bottom and float collar two joints above bottom. Run centralizers on every other joint of casing for bottom 500 feet. Cement casing with sufficient cement to get returns at the surface.

38th 8. Make trip with 2-7/8" work string and condition hole to float collar at approximately 4,420 feet and displace mud in hole with water. Lay down work string.

39th 9. Nipple up 5-1/2" casing and install christmas tree.

10. Test casing and tree to 2,000 psi surface pressure with water in hole. 


\section{ESTIMATED COST \\ OF \\ SALT WATER DISPOSAL WELL \\ FOR \\ STATE LEASE 4183 NO. 1}

\section{Activity}

Estimated

1. Move in rig, drill to 4,000 feet, 12 days \& $\$ 4,200$

$\$ \cdot 50 ; 400$

2. Location preparation

5,000

3. 130 feet of $13-3 / 8^{\prime}: 65$ 非 J-55 plain end casing

4,000

4. 1,200 feet of $9-5 / 8 " 36 \# \mathrm{H}-40$ casing ST\&C or LTC

14,000

5. 4,000 feet of $5-1 / 2$ " 15.5 \# J-55 ST\&C or LT\&C

21,400

6. Stand by rig time

4,200

7. Cement and Services

14,000

8. Ëlectric logging

12,000

9. Perforating

8,000

10. Wellhead equipment

3,000

11. Stimulation

2,500

12. Supervision

3,600

13. Miscellaneous supplies and rentals

7,500

14. Trucking

3,000

15. Contingencies

14,000

16. Material handling at $1.3 \%$ of all items except supervision and contingencies

1,900

Total Well Cost

$\$ 168,500$ 


\section{WELL TEST PROCEDURE}

The well test procedure was established to provide the maximum amount of reservoir rock and fluid information that can be obtained within the fixed time frame subject to the limitations of the available equipment. The only bottomhole pressure device capable of operating at these temperatures and pressures is a 15,000 psi (full scale deflection) Amerada RPG-3 bourdon tube pressure gauge. This gauge has no surface read-out capability and has 3,5 , and 7 day clocks. The maximum accuracy of the bomb is \pm 0.25 percent $(37.5 \mathrm{psi})$ under controlled calibration conditions. These limitations impact the scope of meaningful transient tests which can be conducted.

Before testing commences it will be necessary to flow the well into a reserve pit in order to clean the perforations of mud and foreign solids. After this has been accomplished the well will be shut-in to measure the static reservoir pressure. The well will be placed on production at a low rate through the test equipment in order to establish the drawdown characteristics at a safe level. Every 24 hours the rate will be increased until the choke size which allows flow at 10,000 barrels per day is determined. The well will be shut-in and the pressure build-up recorded. These data will be analyzed to determine the flow capacity of the formation and the skin effect or formation damage.

During each flow period, full flow stream samples will be taken and analyzed for chemical composition. Separator gas-water ratios will be carefully metered to detect changes as a function of the flow rate.

After the well bore pressure has returned to static conditions, the well will be flowed at a rate of 10,000 barrels per day for approximately two weeks. The pressure data from this flow can be used to verify the reservoir parameters computed from the build-up analysis.

At selected intervals throughout the flow periods, separator gas and liquid samples will be taken in order for laboratory recombination studies to be conducted. 
NVO/1528-9A

\author{
TEST PROGNOSIS \\ FOR \\ PAN AMERICAN PETROLEUM CORPORATION \\ STATE LEASE 4183 NO. 1 \\ LITTLE PECAN LAKE AREA
}

Operational

Day

44th 1. Move in and nipple up test equipment. Hydraulically test all systems with water to 4000 psi.

47th 2. Run two Amerada RPG-3 pressure gauges with 24 hour clocks and 15,000 psi full-scale deflection to 15,153 feet, stopping for fifteen minutes each 3,000 feet. Hang bombs for two hours and record surface pressure with deadweight tester. Retrieve pressure bombs.

3. Hook up two-pen pressure recorder to tubing upstream from the choke and to the casing to observe for tubing or packer leaks.

4. Place well on production through adjustable choke at low setting and record surface flowing pressure every thirty minutes by deadweight tester.

5. Record gas and liquid flow rates by calibrating the liquid turbine meter with the test tank. 
NV0/1528-9A

48th 6. Gradually increase the flow rate in increments until either the maximum flow rate from the well or 10,000 barrels per day is achieved. Continue to flow at this rate for 24 hours while recording surface temperature, pressure, and gas and liquid production. If maximum flow rate of well not sufficient, do one of the following:

(1) acidize

(2) perforate more interval

49th 7. Shut well in and measure surface pressure build-up with deadweight tester.

50th 8. When well bore pressure has stabilized, run two Amerada RPG-3 pressure bombs with five day clocks and latch into landing nipple at bottom of tubing.

51st 9. Place well on production at i,050 barrels per day for 24 hours, monitor surface pressure, temperature and flow rates and take the following samples:

(a) Two, one liter, full well stream samples for chemical analysis.

(b) Three, one liter, separator liquid samples.

(c) Two, one liter, separator gas samples.

52nd 10. Increase flow rate to 4,000 barrels per day for 24 hours and sample as before.

52nd 11. Increase flow rate to 7,000 barrels per day for 24 hours and sample as before. 
NV0/1528-9A

53rd 12. Increase flow rate to 10,000 barrels per day for 24 hours and sample as before.

55th 13. Shut well in, measure build-up for 24 hours, then retrieve pressure bombs.

56th 14. Place well on production at low rate and gradually increase rate over a 12 hour period until it reaches 10,000 barrels per day.

15. Flow well at this rate for nine days while measuring surface pressure, temperature and flow rates.

16. Sample as before prior to shutting well in.

67th 17. Shut well in and run two pressure gauges to 16,060 feet and record until deadweight tester at surface indicates static conditions have been reached.

68th 18. Pull pressure gauges, release test equipment and move same out.

19. Proceed with plug and abandonment operations. 


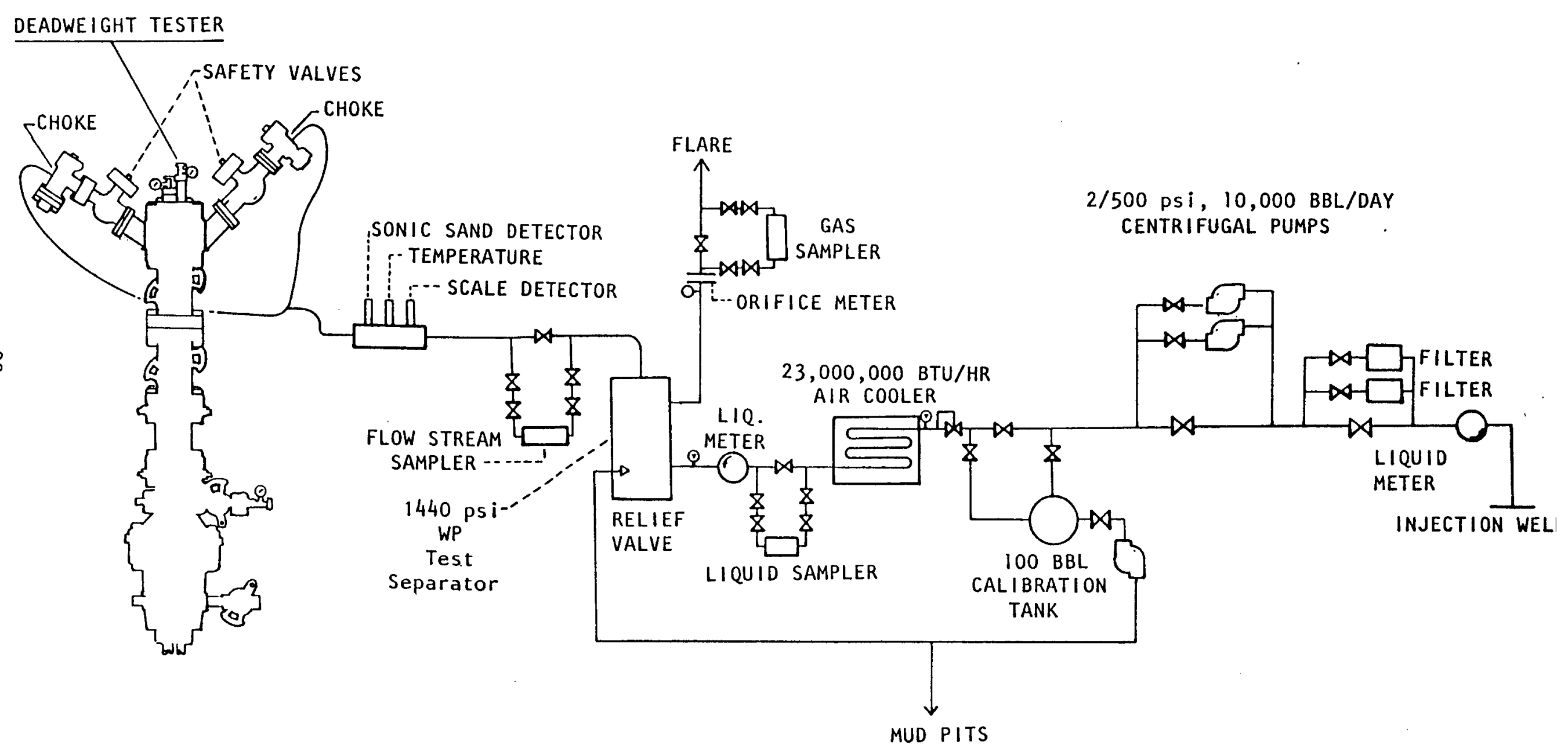

FIGURE VIII

SURFACE TESTING FACILITIES

Gruy Federal, Inc. 


\section{GRUY FEDERAL, INC.}

\section{ESTIMATED TESTING COST \\ For}

STATE LEASE 4183 NO. 1

\section{Activity}

Estimated

1. Two data headers

Amount

2. Two-phase separator

$\$ 108$

3. 100-barrel tank

3,780

4. Two 10,000 BPD centrifugal pumps

1,090

5. $23,400,000 \mathrm{BTU} / \mathrm{hr}$ air cooler

1,940

6. Piping

12,159

(1)

7. Sonic sand detector

740

300

8. Wireline unit $\mathrm{w} / \mathrm{pressure}$ gauge

1,440

9. Gate valve w/activator

500

10. House trailer w/power plant

850

11. Generator

20,000

12. Expansion loops

900

13. Supervision and Labor

46,200

14. Material handling

572

(2)

15. Test Accessories

200

TOTAL

$\$ 90,779$

(1) One charge only of $\$ 8700$ debited to well

for overtime work.

(2) Charged at a rate of $1.3 \%$ on all items except 14. 
STATE LEASE 4183 NO. 1

CAMERON PARISH, LOUISIANA

Analyses Required for $\mathrm{Geo}^{2}$ Water and Gas

Chemical Analysis of Water.

A. Metals

1. Copper

2. Zinc

3. Boron

4. Arsenic

5. Chromium

6. Mercury

7. Lead

8. Cadmiụm

9. Potassium

10. Sodium

B. Solids

1. Dissolved

2. Total

C. Hardness

1. Calcium Carbonate

2. Magnesium Carbonate

D. Others

1. Carbonate

2. Bicarbonate

3. Chloride

4. Iron

5. Sulfate

6. Dissolved Silicate 
STATE LEASE 4183 NO. 1

CANERON PARISH, LOUISIANA

\section{Chemical Analysis of Vapor}

A. Hydrocarbons (percent)

1. Methane

2. Ethane

3. Iso-propane

4. Normal Propane

5. Iso Butane

6. Normal Butane

7. Pentiane

8. $\mathrm{C}_{6^{+}}$

B. Other

1. Hydrogen Sulfide

2. Carbon Dioxide

3. Radon

Chemical Properties of Water

1. Density

2. Compressibility

3. Conductivity

4. Viscosity

5. $\mathrm{pH}^{\mathrm{H}}$

Recombination PVT Analysis

1. Solution gas-water ratio

2. Formation volume factor for water

3. Supercompressibility factor of gas 


\section{GRUY FEDERAL, INC.}

STATE LEASE 4183 No. 1

CAMERON PARISH, LOUISIANA

Analytical Costs for $\mathrm{Geo}^{2}$ Water and Gas

Recombination

2 samples per well

$\$ 10,000$

Chemical Analysis of Water

5 samples per well

750

Material handling at $1.3 \%$

140

TOTAL

$\$ 10,890$ 


\section{PLUGGING AND ABANDONMENT PROCEDURE \\ FOR \\ PAN AMERICAN PETROLEUM CORPORATION \\ STATE LEASE 4183 NO. 1}

1. Move in and rig up pulling unit capable of plugging and abandonment.

2. Nipple up pump trucks to wellhead.

3. Squeeze cement perforations.

4. If squeeze pressure is not obtained overdisplace cement into formation with water and repeat squeeze cementing until successfur.

5. When squeeze pressure is obtained, unbolt christmas tree from tubing hanger, pick up tubing out of packer and reverse excess cement.

6. Remove tree and install BOP's.

7. Run in hole with tubing and set cement plug $100^{\prime}$ in and $100^{\prime}$ out of 5" OD Tiner.

8. Pull tubing and set a plug from $50^{\prime}$ to surface.

9. Cut off $13-3 / 8^{\prime \prime}$ casing $3^{\prime}$ below ground level and weld on plate.

10. Release rig.

11. Send tubing and casing to pipe yard for inspection and repair.

12. Send christmas tree to shop for overhaut. 


\title{
GRUY FEDERAL, INC.
}

\author{
ESTIMATED PLUGGING COSTS \\ For \\ PAN AMERICAN PETROLEUN CORPORATION \\ STATE LEASE 4183 No. 1
}

LITTLE PECAN LAKE AREA

\section{Activity}

1. Pulling unit at $\$ 1,000 /$ day

2. Rental tools at $\$ 500 /$ day

3. Trucking

4. Cement and services

5. Supervision

6. Contingencies

7. Material handling on all above items except supervision and contingencies at $1.3 \%$
Arount

$\$ 4,000$

4, 000

3,000

4,000

2,000

2,400

300

400

8.

TOTAL 


\section{GRUY FEDERAL, INC.}

5. Are known archeological sites, historic sites, or natural landmarks within or visible from the site area?

Yes__ No $\mathrm{X}$ If yes, explain.

6. Will expected continuous noise levels from site operations be $65 \mathrm{dBA}$ or less at the nearest residence?

Yes_ $X$ No__ If no, explain.

\section{B.. SITE CONSTRUCTION}

1. Will additional land clearing be required for the test well (e.g., drill pad, road construction, mud reserve pits, pipeline)?

Yes No $\mathrm{x}$ If yes, describe.

2. Will additional land clearing be required for the disposal well (e.g., drill pad, reserve pits, utilities, road construction, pipeline)?

Yes __ No $X$ If yes, describe. 


\title{
GRUY FEDERAL, INC.
}

\author{
SITE-SPECIFIC ENVIRONMENTAL INFORMATION CHECKLIST \\ GEOPRESSURED-GEOTHERMAL WELL TEST PROGRAM \\ GRUY FEDERAL, INC. \\ NO. $\mathrm{L}-5$ \\ STATE LEASE NO. 4183 No. 1
}

\section{A. GENERAL}

1. Is the proposed site located in the area covered by the

"Gulf Coast Programmatic: Environmental Assessment; Geothermal

Well Testing, the Frio Formation of Texas and Louisiana October 1977"?

Yes $\mathrm{X}$ No___ If no explain.

2. Has a federal, state and/or local environmental assessment been conducted previously for the proposed test well or other wells in the area?

Yes_No No If yes, provide a copy, if available.

3. Have all required permits, licenses, and/or agreements for proposed project been obtained?

Yes_ No $X$ If no, explain.

All permits have been obtained except the Louisiana

Wildife \& Fisheries Commission which is expected by

June 21, 1978. The concurrence of the oil \&:gas lease holder, Amoco Prod. Co. has not yet been received.

4. Does the project site fall within the habitat of rare or endangered species?

Yes_ No $\mathrm{X}$ If yes, explain. 


\section{GRUY FEDERAL, INC.}

3. Will the site and related roads be treated to minimize dust?

Yes_ No No $X$ If no, explain.

Road and work site to be boarded.

4. Are portable sanitary facilities or an approved septic system to be used at the site?

Yes $X$ No__ If no, explain.

5. Will liquid and solid wastes be disposed in accordance with local regulations?

Yes_X No___ If no, explain.

6. Will erosion control be required for excavated areas? Yes__ No $\mathrm{X}$ If yes, explain.

7. Will dredge spoil be deposited in swamp forest or marshland? Yes_ No $\mathrm{X}$ If yes, explain.

8. Upon completion of proposed test program, will the site be restored to as natural a condition as possible by regrading, filling, and reseeding?

Yes $\mathrm{X}$ No If no, explain. 


\section{GRUY FEDERAL, INC.}

\section{WELL TESTING AND SAFETY}

1. Is fluid production from the well during testing expected to be 2 weeks or less in duration per formation?

Yes_ No $\mathrm{X}$ If no, explain.

Planned to test for 30 days.

2. Is the total dissolved solids of the produced geopressure fluid expected to be $90,000 \mathrm{mg} / \mathrm{l}$ or less?

Yes $\mathrm{X}$ No___ If no explain.

3. Is the volume of geopressure fluid to be produced and injected expected to be $3,000,000$ barrels or less?

Yes_ $\mathrm{X}$ No___ If no, explain

4. Is the temperature of produced geopressured fluid expected to be $260^{\circ} \mathrm{C}$ or less?

Yes $\mathrm{X}$ No____ If no, explain.

5. Will the gas content of the produced fluid be flared? Yes $\mathrm{X}$ No___ If no, explain.

6. Will blowout preventers rated to at least $10,000 \mathrm{PSI}$ be used?
Yes $\mathrm{X}$
No
If no, explain. 
GRUY FEDERAL, INC.

7. Will production tubing rated to at least 20,000 psi, be used?

Yes_ No $\mathrm{X}$ If no, explain.

Pressure rating is $18,000 \mathrm{psi}$ and is of substantial safety factor.

8. Can safety valves be operated from remote locations? Yes_ X No If no, explain.

9. Will the test tree be rated to at least $10,000 \mathrm{psi}$ Yes_X No___ If no, explain.

10. Will a test well directional survey be conducted?

Yes_ No $\mathrm{X}$ If yes, at what interval? Feet.

Well already drilled and cased.

11. Will a lined pond be used to hold all liquid effluents and production fluids that are not injected?

Yes $X$ No_ If no, explain.

12. Has an injection permit been obtained?

Yes No $X$. If no, explain.

Permit pending and expected by 3rd week in June 1978. 


\section{GRUY FEDERAL, INC.}

13. Will $\mathrm{H}_{2} \mathrm{~S}$ monitors be located onsite?

Yes_ No $\mathrm{X}$ If no, explain.

No history of $\mathrm{H}_{2} \mathrm{~S}$ in area.

14. Will fire extinguishers be located onsite?

Yes_X No__ If no, explain.

15. Do contingency plans exist for evacuating personnel should a blowout occur or high levels or $\mathrm{H}_{2} \mathrm{~S}$ be detected? Yes $X$ No_ If no, explain.

16. Will high-pressure engineering and mud logging personnel be onsite during production well drilling operations?

Yes_ $X$ No___ If no, explain. 
